\title{
Szemle
}

\section{FODOR LÁSZLÓ*}

\section{Kommunális környezetvédelem német szemmel}

A Trieri Egyetem Környezet- és Műszaki Jogi Intézete (Institut für Umwelt- und Technikrecht der Universität Trier, Németország) 2014. évi konferenciájának a címe Kommunaler Umweltschutz, azaz kommunális környezetvédelem volt. ${ }^{1}$ A mérsékelt érdeklődés mellett zajló (az intézeti konferenciasorozat immár 30. elemeként sorszámozott) rendezvényen ugyan személyesen nem vehettem részt, azonban a szervezők jóvoltából megkaptam a 2015 júniusában megjelent kötetet, amely részletesebben, kidolgozottabban adja vissza az elhangzottakat. ${ }^{2}$ Amint a levezetöelnök (Timo Hebeler, Trier) megnyitójából is kiderül, az intézet 15 évvel ezelött már foglalkozott a kérdéskörrel, némileg más megvilágításban (Umweltschutz, Wirtschaft und kommunale Selbstverwaltung - azaz Környezetvédelem, gazdaság és helyi önkormányzás cím alatt), azonban a téma örökzöld, megéri leporolni. Ennek oka egyrészt, hogy különféle társadalmi és gazdasági körülmények nyomán a jogrend egyre nagyobb szerepet szán a környezetvédelem, illetve környezetgazdálkodás terén a helyi önkormányzatoknak, másrészt az ágazati szabályozás is számos újdonságot hoz, a klasszikus szerepkörök mellett (például hulladékgazdálkodás, településrendezés) újabb területeken is (mint az energiajog és a hálózatok fejlesztése). Ezek az aktualitások vezérelték a program összeállítását, illetőleg a kötet szerkesztését. És éppen ezek azok a gyorsan fejlődő szakterületek, amelyek - vagy legalábbis a mögöttes problémák, kihívások - hasonlósága miatt Magyarországon is aktuális az önkormányzati környezetvédelem témaköre, és amire tekintettel ez az ismertetés elkészült.

A hagyományosan kétnapos rendezvény elöadói nemcsak kutatók, egyetemi tanárok voltak, hanem akadt köztük több olyan gyakorlati szakember is (jelen esetben

* Dr. Fodor László egyetemi tanár, Debreceni Egyetem Állam- és Jogtudományi Kar Agrárjogi, Környezetjogi és Munkajogi Tanszék, fodor.laszlo@law.unideb.hu. A recenzió a K 115530 ny. sz. OTKA kutatási projekt keretében, illetöleg az MTA Bolyai János Kutatási Ösztöndij támogatásával készült.

1 Az intézet 2013. évi, az energiafordulat jogi kérdéseit taglaló konferenciájáról a Pro Futuro 2013/2. számában számoltam be. Fodor László: A németországi energiafordulatról. Pro Futuro 2013/2, 111-119.

2 Hebeler, Timo-Hendler, Reinhard-Proel $\beta$, Alexander-Reiff, Peter (Hrsg.): Kommunaler Umweltschutz. 30. Trierer Kolloquium zum Umwelt- und Technikrecht vom 4. bis 5. September 2014. UTR Band 128, Erich Schmidt Verlag, Berlin, 2015, 218. 
ügyvéd és önkormányzati referens), aki a praktikus megközelítést érvényesítette. A konferencia egyes blokkjait vita zárta, amit a kötet szerkezete is követ. A vitákról készült összefoglalókat, mint mindig, a házigazda-intézet doktoranduszai írták, szinte jegyzőkönyvi részletességgel, esetenként az egyes konferenciacikkekéhez közelítő terjedelemben.

A nyitó előadás - Thorsten Ingo Schmidt (Potsdam) - igen vázlatos áttekintést nyújt a kérdéskör alkotmányjogi és Európa-jogi kereteiröl. A korábbi szakirodalmi adatokkal egyezően arra a megállapításra jut, hogy a környezetvédelem nemcsak a szövetségi állam és a tartományok feladata (mint az az alkotmányjogi rendelkezésekböl közvetlenül fakad), hanem az önkormányzatoké is, ugyanakkor ennek konkrét tartalma csak a szövetségi és tartományi előírásokból derülhet ki. A vizsgálat négy dimenziója közül (ti. az önkormányzatok viszonya a szövetségi államhoz, a tartományhoz, a polgáraihoz és egymáshoz) föleg a polgárokkal való viszonyt vizsgálja, megállapítva, hogy a lakosok a helyi önkormányzattal szemben csak kivételesen érvényesíthetnek környezeti igényeket (annak megfelelően, hogy a német alkotmányjog nem ismeri el a környezethez való jogot), ${ }^{3}$ ugyanakkor számos alapjog gyakorlása értelmezhető ennek inverzeként (a szerző némileg provokatív megfogalmazásával élve), a környezet terheléséhez való jogként (például a gyülekezési jog és a közterületek tisztasága, helyváltoztatás és közlekedési eredetü légszennyezettség).

Ugyanezt a gondolatsort viszi, mélyíti tovább Florian Becker (Kiel), aki az EU hetedik környezetvédelmi akcióprogramjának célkitüzéseit véve alapul a helyi önkormányzatokat mind az uniós, mind a nemzetközi környezetpolitika egyik legfontosabb megvalósítóinak tekinti (megjegyzendő, hogy az uniós program maga is utal az ENSZ égisze alatt kidolgozott Local Agenda 21 folytatására). A „Think global act local" (gondolkodj globálisan, cselekedj lokálisan) közismert tételét megvalósítva a német helyi önkormányzatok az 1980-as évek vége óta egyre több hatáskört és feladatot kapnak (a településrendezés, a közszolgáltatások szervezése, a saját szolgáltatásaik és beszerzéseik terén, s ezzel együtt) a környezetvédelem területén, ami mögött részben az alaptörvény 28. cikkében deklarált önkormányzatiság áll. A helyi cselekvési szinttel szembeni bizalmatlanság, elégedetlenség a szerző szerint nem jelenthet jogalapot az önkormányzati hatáskörök csorbítására, illetöleg centralizálására, hiszen magára a központi államra is ugyanúgy hatékonysági problémák jellemzők. Nem szabad megfeledkeznünk emellett a polgárokhoz (ügyekhez) közeli közigazgatás és a (vertikális) hatalommegosztás előnyeiről sem. Külön indokolásra méltónak tartotta a klímavédelmi hatásköröket, aminek elsősorban természettudományos okai vannak (a klímaváltozás globális probléma). A szerző okfejtése tulajdonképpen azt (a későbbi tanulmányok némelyikében szintén felmerülő problémát) mutatja be, hogy a klímavédelmi ügyek helyi sajátosságai (mint az önkormányzati fellépést megalapozó körülmények) nem mindig ismerhetők fel, de ennek ellenére minden önkormányzatnak meg lehet és kell is tennie a megfelelö lépéseket. (A szerzői gondolatmenetet továbbfüzve: bízva abban, hogy a többi önkormányzat is hasonlóan jár el, azok intézkedései összességükben hozzák meg a kívánt eredményt.) Az energiaügy (településrendezés, monitoring, közszolgáltatások), a víz- és hulladék-

3 Fodor László: Környezetvédelem az Alkotmányban. Gondolat-DE ÁJK, Budapest, 2006, 71-101. 
gazdálkodás feladatai (vízellátás, szennyvízkezelés, hulladékkezelés) a közlekedés (forgalomszervezés, közösségi közlekedés szervezése), a helyi adók (környezetterhelési és igénybevételi adók) területén végzett rövid állapotfelmérés tükrében arra a következtetésre jut a szerzö, hogy az önkormányzatok környezetügyi kompetenciái körében nem várható és nem is indokolt áttörés, hiszen máris rengeteg feladatuk és hatáskörük van az önkormányzatoknak. Ahol növelhetö az önkormányzatok szerepe, az a megrendelői és szolgáltatói szerepkörben való példamutatás (amit az uniós környezetpolitika vagy a német szövetségi energetikai jogszabályok is hangsúlyoznak), és ezzel a helyi közösségek környezeti tudatosságának javítása.

Ralf Brinktrine (Würzburg) nem általában a környezetügy, hanem kifejezetten az energiaszektor területén vizsgálódik. A kommunális energiajog jelentőségének megvilágítására olyan tényadatokat hoz fel, mint az önkormányzati szerepvállalás arányszámai (57\%-os piaci részesedés a lakossági áramellátásban, 700-nál is több kommunális gáz- és áramszolgáltatóval, illetve 850-nél is több kommunális elosztói hálózatüzemeltetővel). Ahogy fogalmaz, az önkormányzati szerepvállalás - párhuzamosan a megújuló energiák térhódításával - egyre csak nő, ami kívánatos és elvárt egyben, ugyanakkor számos jogi problémát vet fel. Kötelesek-e az önkormányzatok maguk szolgáltatni az energiát $s$ ehhez a hálózatot üzemeltetni? Elvárható-e tölük a megújuló energiahordozók használata? Részesedhetnek-e energetikai vállalkozásokban? Nyújthatnak-e szolgáltatást közigazgatási határaikon kívül? Elöírhatnak-e szerződéskötési kötelezettséget, illetve csatlakozási kötelezettséget a hálózatukhoz? Mennyiben kötelesek példát mutatni a középületek energiahatékonysági tulajdonságainak javításával? Az önkormányzatok legkülönfélébb szerepköreit felvillantó, problémaorientált megközelítésben utal a szerző a szabályozás alkotmányjogi hátterére, nemcsak az önkormányzatiság garanciáit (a központi állammal szemben is védett önkormányzatiságot, a helyi közügyek vitelére való jogosultságokat), hanem a szövetségi alaptörvény környezeti rendelkezését (például az energiahatékonysági intézkedéseknek jogalapot szolgáltató, 20a cikket) is felhíva. Külön érdekessége a tanulmánynak, hogy a tartományi alkotmányokat is áttekinti, amelyek közül négy is kifejezett rendelkezéseket tartalmaz az önkormányzatoknak az energiaszektort érintő feladataira (mint például a közvilágítás, a gáz- és áramellátás). Az egyes önkormányzati szerepkörökhöz kapcsolódóan - a hazaitól igen eltérő szerkezetü - törvényi szintű rendelkezések lényegét is összefoglalja a szerző.

Axel Kafka (Köln) a kommunális energiajog fejlödésének motorjaként a rekommunalizációt tekinti, mint ami szervesen illeszkedik az energiarendszer átalakulásának - a hagyományos, nagyerőmüvekre épülő, centralizált rendszerről a helyi hálózatokból álló, decentralizált szerkezetre való átállásnak - a folyamatába. Nem csupán a rekommunalizáció formáit (az elosztói hálózat önkormányzati tulajdonba vétele/ visszavétele, a hálózatüzemeltető cégben való részesedés visszavásárlása, különböző együttmüködési formák az önkormányzat és a vállalatok között), hanem annak okait is számba veszi. Utóbbiak közül számunkra is figyelemre méltó lehet a nagyobb önkormányzati befolyás a szolgáltatások minőségére és árára, a többi közszolgáltatással (különösen a vízellátással) megvalósítható koordináció, nagyobb társadalmi elfogadottság (az önkormányzati vállalatokkal szembeni bizalom a gazdasági válság hatására nőtt, ugyanakkor az önkormányzatok nagyobb mértékben 
tudják bevonni projektjeikbe a helyi közösségeket). A rekommunalizációval szembeni, gyakran hivatalos álláspontokban is megjelenő szkepszist a gyakorlati tapasztalatokkal oszlatja el a szerző, ugyanakkor arra is rávilágít, hogy - különösen a napjainkban lejáró koncessziók, és az új szerződések megkötése körében - számos jogi probléma merül fel, amelyeket a bírói gyakorlat csak korlátozottan képes megoldani. Alkalmas-e a koncesszió az önkormányzat és a koncesszióvevő közötti együttmüködés elmélyítésére? (Például kiköthetö-e mellékszolgáltatásként, hogy a társaság segít az önkormányzatnak települési energia-, illetve klímaprogramot készíteni?) Mely (ki által használt) hálózatokra terjedhet ki a koncesszió? Alkalmazható-e a konceszszióra az EU Bírósága által a közbeszerzésekre kidolgozott követelményrendszer? E kérdésekre keresve a választ, a szerző - a törvényi szabályozást hiányolva - egyelöre csak a bírói fórumok válaszát hívhatta fel.

Klaus Ritgen (Berlin) az egyik legizgalmasabb (a közhatalmi intézkedések legitimációja szempontjából klasszikusnak számító) kérdést állította célkeresztbe, amennyiben a hálózatfejlesztési projektek társadalmi elfogadottságának a feltételeit vizsgálta. Ilyen beruházások nélkül az energiarendszer átalakítása nem képzelhető el, s mint a tanulmányból kiderül, az átviteli hálózatok tervezése során 2013-tól új szabályok szerint kell biztosítani a nyilvánosság részvételét (ezek egyébként az elosztó hálózatoknál nem érvényesülnek). Még alig áll rendelkezésre tapasztalat az új elöírások érvényesüléséröl, ugyanakkor az már biztos, hogy túl korai fázisban kerül sor a nyilvánosság biztosítására, amikor (például a konkrétan érintett ingatlanok ismeretének hiányában) a konfliktusok még alig körvonalazódnak. Ráadásul az ilyen eljárásokban keletkező iratok (például hálózatfejlesztési tervek, környezeti értékelés, hatósági állásfoglalások) rendkívül terjedelmesek, és a megismerésük aligha realitás a lakosok részéröl. A szerző a különféle érdekek latolgatása (NIMBYjelenség, egyéni és közérdekek gyakran nehezen felismerhető viszonya, szükebb és tágabb környezet eltérő érintettsége) alapján arra jut, hogy igen nehéz növelni az ilyen beruházások elfogadottságát, $s$ ezt követően tér rá arra a kérdésre, hogy mit is jelent jogi szempontból ez az elfogadottság. Világos, hogy az nem érvényességi kellék (például egy engedély esetén), mint ahogyan az is, hogy a demokratikus legitimációnak sem feltétele (ugyanakkor arra is rávilágít a szerző, hogy ha egy döntésnek érvényességi kelléke lenne a közvetlenül érintettek egyetértése, az egyenesen antidemokratikus megoldás lenne, hiszen a legitimáció forrása egyedül maga a nép - egésze - lehet). Ugyanakkor mégis célja kell hogy legyen ez az eljárásoknak, hiszen az elfogadottság a döntés helyességét is mutatja, és a végrehajtás (jogkövetés) terén is többletértéket ad a döntésnek.

A tanulmány utolsó része foglalkozik azzal, hogy milyen módon javitható helyi szinten az elfogadottság, például az elosztó hálózatok tervezésénél, engedélyezésénél. Felveti a közvetlen demokrácia erősítését (ügydöntő népszavazások - amelyek szabályozása tartományonként eltérő képet mutat), a lakossági tájékoztatás nem kötelező formáinak szorgalmazását (nyílt napok, workshopok, projektirodák létrehozása stb.), a pénzügyi részvétel (részesedés) lehetőségének a biztosítását (ami lakossági szélparkok esetén már müködik), s végül a „kompenzációt” is, amit a német jogrend az állampolgárok vonatkozásában nem ismer (természetesen kártalanítás létezik, ha valakinek az ingatlanát közvetlenül érinti egy beruházás), ugyan- 
akkor az önkormányzatok kapnak ilyet (a településen átmenő vezeték hosszától függő mértékben). Azt a kérdést, hogy célszerü lenne-e ilyesfajta (magyar szemmel nézve kissé bizonytalan jogi megítélésű) pénzügyi eszköznek az alkalmazása a lakosok esetében is, a szerző már nyitva hagyja. Számos felvetése közül ez volt az egyik, amely parázs vitát váltott ki a konferencián: a beruházásoknak ugyanis vannak közvetett hatásai, peres úton nem érvényesíthető hátrányai (mint amilyen az ingatlanok forgalmi értékének csökkenése, ami szélparkok esetén a zajterhelés miatt még az elöírt védőtávolságon kívüli területeken is megfigyelhetö), amelyeknek a kompenzálása sokak szerint érdemben javítaná az elfogadottságot.

Anja Hentschel (Kassel) a településrendezés környezetvédelmi kérdései közül vett szemügyre néhányat. A településrendezés általános környezeti összefüggésein túl, a leginkább időszerű klímavédelemnek, illetve a megújuló energiatermelés feltételeinek szentelte a legtöbb figyelmet. Kiindulópontként a területrendezés és a környezetvédelem egyre szorosabbá váló kapcsolatát érzékelteti, egy kis szabályozástörténeti vázlattal. A jelenlegi szabályozási helyzetképet a szövetségi épitési törvény rendelkezései alapján mutatja be, kezdve a településrendezés törvényi céljaitól, amelyek közt az emberhez méltó környezet biztosítása, az élet természeti alapjainak védelme, illetőleg a klímavédelem és a klímaváltozáshoz való alkalmazkodás egyaránt szerepel. Az önkormányzatok által a tervezés során figyelembe veendő szempontokat példálózó felsorolás formájában rögzíti a törvény, s ebböl a felsorolásból látszik legjobban az, hogy az önkormányzatok környezetvédelmi feladatai nem szükülnek le a szaktörvényekben rögzítettekre vagy a kötetben kifejtettekre (amelyek még szükebb kört jelentenek), hanem a kulturális és épített örökség, a növények és az állatok, vagy a klíma védelmétöl a természet-, föld-, levegö- és tájvédelmen keresztül a hulladékok és szennyvizek megfelelő kezelésére, az energiatakarékosságra és a megújuló energiahordozók használatára is kiterjed. A konkrét rendelkezések, illetőleg az önkormányzati tervezési gyakorlat alapján a szerző különösen pozitívnak értékeli, hogy a klímaváltozással kapcsolatos intézkedések mindkét oldala megjelenik.

Kapcsolódó jogintézményként ismerteti és méltatja a tervek elfogadása előtt hazánkhoz hasonlóan - kötelezően lefolytatandó környezeti vizsgálat jelentőségét. Míg nálunk ezt az eszközt sokszor formalitásnak tekintik, vagy épp el is marad az alkalmazása, mind a szerző, mind vitapartnerei (különösen Reinhard Hendler, Trier) véleménye szerint Németországban már a puszta bevezetése is érdemi javulást hozott a települési környezetvédelemben. Tekintve, hogy a jogintézmény hazai szabályozása és gyakorlata igen sok hiányosságban szenved, néhány innovatív megoldás különösen figyelemre méltó. llyen például, hogy a vizsgálatok szempontjainak meghatározásában az önkormányzatok maguk is szerepet kapnak (standardizálva csak a vizsgálati módszerek vannak, amin túl a jogszabályok a mindenkori tudományos ismeretek alkalmazását és a megfelelő részletességet írják elö). Az is hasznos, hogy a környezeti értékeléssel nem ér véget a hatásvizsgálat, ugyanis az önkormányzatoknak utólagos nyomon követési kötelezettségük is van, amelynek az eredményétöl függően a nem várt, negatív környezeti hatások kiküszöbölésére is intézkedéseket kell hozniuk. 
Anette Guckelberger (Saarbrücken) a településeknek a hulladékgazdálkodásban betöltött szerepéröl írt tanulmányt, amely jól illusztrálja, hogy a hulladékkezelési közszolgáltatók - illetve maguk az önkormányzatok - és a hulladékkezeléssel foglalkozó magánvállalkozások közötti, az értékes hulladékokért folyó küzdelem hogyan csapódik le a jogszabályok értelmezése körüli vitákban. A bemutatott helyzetképet talán úgy lehetne összefoglalni, hogy a tételes jog nehezen értelmezhetö, de a szövetségi közigazgatási bíróság útmutatásai révén biztosított az egységes alkalmazás és az uniós jognak való megfelelés is. A bírói gyakorlatra nagymértékben támaszkodó írás néhol elszakad a címében jelzett témától, és olyan eljárásjogi kérdésekre is kitér, mint a hulladékkezelési tevékenység bejelentési kötelezettsége (a vállalkozás által benyújtandó dokumentumok részletezése mellett), és az ahhoz kapcsolódó (egyébként általában inkább az engedélyköteles tevékenységeknél megjelenő), széles körü ellenőrzés koherenciazavara. Megjelennek ezenkívül anyagi jogi problémák is, mint például a hulladék átadásának a kötelezettsége, az ezzel kapcsolatos normák értelmezési zavara, ami azonban már szorosabban kapcsolódik ide, hiszen e szabályok értelmezésén múlik a közszolgáltató és a piaci vállalkozások közötti választás (amit a nem háztartási eredetű kommunális hulladékoknál, illetve a szelektíven gyüjtött háztartási hulladékok esetén enged meg a szabályozás, bizonyos feltételekkel). Bár e normák tartalma több tekintetben is hasonló a mienkhez, számunkra inkább az önkormányzatok helyzetének a taglalása az érdekesebb, ahol már egészen más a helyzet. A német önkormányzati rendszer ugyanis más (többszintű), és árnyalja a képet a föderális berendezkedés is (tartományonként eltérő a szabályozás, illetve más és más szintü önkormányzat a felelős a kommunális hulladékok kezeléséért). Egyes tartományokban egyébként a hulladékkezelésért felelös önkormányzat hulladékgazdálkodási hatósága látja el a kommunális hulladékok felügyeletét is, ami felvet bizonyos kételyeket a jogállamiság követelményeinek érvényesülését illetően (lehet-e a saját gazdasági érdekeket félretenni?), amelyeket az érintettek a két funkció szervezeti elkülönítésével igyekeznek eloszlatni.

Az egyes tanulmányok részletes áttekintése, illetöleg a viták összefoglalóinak a szemlézése alapján összességében elmondható, hogy a kötet némileg szükebb körben tartalmaz elemzéseket annál, mint amit meglehetősen általános címe takar. Sok részletkérdés, ágazati szempont (földvédelem, természetvédelem, vízvédelem stb.) tekintetében más forrást kell keresnie a német helyi önkormányzatok környezetvédelmi feladatairól és jogosítványairól tájékozódni kívánó olvasónak. Első ránézésre az is kritikának lehet alapja, hogy a bevezetőnek szánt egy-két tanulmányból alig tudhatunk meg újat, ugyanakkor az általános és speciális problémakörök, okfejtések egymásra épülése révén ez mégsem okoz hiányérzetet. A részleteiben is kidolgozottabb témák (energia, hulladék, településrendezés) esetében a kötet kétségkívül hasznos segítség, jól fókuszált pillanatkép mind a felmerülő problémákról, mind a hatályos szabályozásról. A német önkormányzati rendszer vagy a közszolgáltatások iránt érdeklődőknek is számos adalékkal szolgál. A viták összefoglalása pedig azt is remekül mutatja, hogy milyen sokféle elméleti és gyakorlati megközelítésben lehet mindezekről gondolkodni.

Ha egyetlen általános, hazánkban is megszívlelendő tanulságot kellene levonni a bő kétszáz oldal elolvasása alapján, akkor leginkább azt emelném ki, hogy a 
helyi önkormányzatokat a német jogrend nagykorúként kezeli. Ha kétely merül fel valamely feladat önkormányzati szintü ellátásának a hatékonysága felöl, akkor nem feltétlenül az a megoldás, hogy elvonjuk tölük a feladatot - talán többre megyünk, ha megadjuk hozzá a megfelelő eszközöket. 